Stoeckl, Kristina: "The lesson of the revolution in Russian émigré theology and contemporary Orthodox thought." Religion, State and Society 4 (2007), 285-300.

\title{
The Lesson of the Revolution in Russian Émigré Theology and Contemporary Orthodox Thought
}

\section{KRISTINA STOECKL}

\begin{abstract}
This paper cuts across the whole spectrum of Orthodox thought in Russia today, both clerical and lay, both theological and philosophical, in order to show the different ways in which Orthodox thinkers have reflected (or not reflected) upon the experience of totalitarianism. The point which I want to make here is that many representatives of Russian Orthodoxy - and most casual western observers - overlook 'the lesson taught by the revolution'. This lesson is expressed in the need to formulate clear standpoints on the totalitarian challenge from within the Orthodox theological tradition. Russian émigré theology and its contemporary heirs have embarked upon this path; the Russian Orthodox Church has not, or has done so to a much lesser extent.
\end{abstract}

\section{Introduction}

The divided Europe of the twentieth century shared one experience: that of totalitarianism. Whether Fascism and Nazism in the West or Stalinism in the East, in both parts of Europe totalitarianism raised the same question: what had gone wrong so as to make totalitarianism possible?

In the West, the idea that totalitarianism did not signify the collapse of the modern political order, but, on the contrary, realised one of its intrinsic possibilities, was articulated by various scholars who found themselves, during their lifetime, confronted with totalitarian rule. Jacob Talmon, for example, in The Origins of Totalitarian Democracy, first published in 1951, holds that totalitarian democracy is an integral part of the western political tradition. Talmon points out that 'totalitarian democracy early evolved into a pattern of coercion and centralization not because it rejected the values of eighteenth-century liberal individualism, but because it had originally a too perfectionist attitude towards them' (Talmon, 1986, pp.1-2). ${ }^{1}$ In twentieth-century western philosophy, reflection upon this insight has resulted either in attempts to strengthen (Rawls, 1973; Habermas, 1981) or to deconstruct (Lefort, 1986; Nancy, 1991) the liberal individualist paradigm. The latter trend is usually referred to as 'postmodernism' and its main thrust 
Stoeckl, Kristina: "The lesson of the revolution in Russian émigré theology and contemporary Orthodox thought." Religion, State and Society 4 (2007), 285-300.

has been to bring to the fore the totalitarian potential inherent in modern forms of framing the social and the political (Lefort, 1988).

In the East, the experience of totalitarianism equally signified a watershed for an intellectual tradition which played an important role in nineteenth- and early twentiethcentury Russia: Russian religious philosophy and Orthodox theology. Orthodox thinkers had to recognise that for Orthodoxy too the collapse of community into a totalitarian collectivity and collaboration with a totalitarian regime was a reality. Collectivism has often been taken as an intrinsic feature of Russian culture, a kind of national characteristic that becomes visible in Soviet communism but represents, in reality, the social, political and cultural legacy of the Orthodox religion. ${ }^{2}$ The Soviet semioticians Yuri Lotman and Boris Uspensky expressed the view that Russia and the West were bearers of two distinct religiously motivated cultural patterns: the pattern in the West had given rise to individuality and agency and a continuous cultural development from Renaissance to Reformation to Enlightenment; whereas Russia had remained caught in collectivism and passivity, and in a medieval mindset with outbursts of radical modernisation (Lotman and Uspensky, 1977). In short, Orthodoxy is said to have prevented the individualisation, political emancipation and modernisation of Russian society. It should not come as a surprise that with the experience of totalitarianism in the twentieth century Orthodox thinkers would eventually reexamine such interpretations of the Orthodox cultural, social and political legacy and thereby respond to the challenge of totalitarianism. In this paper it is my intention to show that such a reexamination and development of the Orthodox intellectual tradition did indeed take place in the Russian diaspora and in Soviet and postsoviet Russia.

\section{The Experience of Totalitarianism and its Impact on Russian Orthodox Thought}

The first instance of Orthodox self-scrutiny is the well known collection of essays from 1909 about the Russian intelligentsia, Vekhi (Landmarks). This is a text which, reflecting on the revolution of 1905 , points out the weaknesses of the intellectual and spiritual quest of the Russian intelligentsia, in remarkable anticipation of what was to follow later on. In this text, Nikolai Berdyayev and Sergei Bulgakov, to name the two 
Stoeckl, Kristina: "The lesson of the revolution in Russian émigré theology and contemporary Orthodox thought." Religion, State and Society 4 (2007), 285-300.

most prominent contributors, identify the high aspirations of the prerevolutionary Russian intelligentsia as to blame for the failure of the revolution. In what amounts to a clear denunciation of the totalitarian democratic spirit of the prerevolutionary intelligentsia and of much religiously-inspired philosophising about Russia, Bulgakov writes: 'unless we take into account [...] the historical lessons of the revolution, we can make no positive statement about Russia; nor can we fall back on the clichés of either the Slavophiles or the Westernizers' (Shatz and Zimmerman, 1994, p. 17). 'The historical lessons of the revolution' which Bulgakov is invoking here comprise the recognition that the social, political, and, most importantly, intellectual and spiritual quest that dominated the Russian intelligentsia had led to disastrous results. Going back to the dominant themes of the philosophical discourse of the nineteenth century, for example the socio-political catchword sobornost', was no longer a viable option. ${ }^{3}$ What was needed was a renewal of Orthodox thought in the light of the weaknesses which the political upheaval and societal disorientation of the early twentieth century were bringing to the fore.

The second instance of reexamination of the situation of Orthodoxy, this time after and in the light of the Bolshevik revolution and totalitarianism, is the debate among Russian émigré theologians known as the 'Sophia Controversy'. There is no need here to explain in detail the rivalry between the two theological schools which Paul Valliere has described as Russian School theology and Neopatristic theology (Valliere, 2001, 2000). ${ }^{4}$ The conflict between Bulgakov and Florovsky has been described as a debate between modernists and traditionalists (Bird, 2003) or between liberals and conservatives (Schmemann, 1972), or as an encounter between the desires to lead Orthodox theology 'back to the fathers' or 'beyond the fathers' (Valliere, 2000). I shall argue, however, that none of these designations quite exhausts what was at stake. The theological dispute between the two schools did not arise around the question whether the Orthodox Church needed a renewal after centuries-long stagnation and western influence - on this there was consensus - nor even on the issue as to whether the Church should be engaged in the world - this also was a shared view - but on the question on which basis such a renewal and engagement with the world could take place. For Bulgakov, the two issues were clearly linked. The renewal of the Church would take place on the basis of an active social engagement in the world. Florovsky, on the other hand, thought that the Church 
Stoeckl, Kristina: "The lesson of the revolution in Russian émigré theology and contemporary Orthodox thought." Religion, State and Society 4 (2007), 285-300.

needed first and foremost to reappropriate its dogmatic foundations, to achieve a spiritual renewal, and from this a true engagement with the world would follow.

I want to argue that not only Bulgakov's attempt to modernise Orthodoxy, but also Florovsky's reexamination of the historical and theological roots of Orthodoxy, should be considered as different modes of responding to the challenge of totalitarianism. The word 'response' is important here: both these schools took issue with the totalitarian potential of their own tradition and of western modernity and they sought to come to terms with it in very different ways. Neither an uncritical subscription to the tradition of Russian Orthodoxy nor a wholesale embrace of western Enlightenment were viable options at a point in time where totalitarianism had brought to the fore the negative potential of both. The Russian School was inspired by the Marxist critique of western capitalism; its ideal was an engaged Church that would assume an active role in the life of modern society but would not repeat the mistakes of revolutionary socialism. The Neopatristic thinkers grounded their response to totalitarianism on an entirely different basis. Neopatristic theology took a perspective outside the modern world, namely in the Patristic tradition, yet it did so in order to draw from there the conceptual tools for an engagement with the modern world. ${ }^{5}$

Both Russian religious philosophy and émigré theology find a continuation in Soviet and postsoviet Russia. In my analysis, I distinguish between two areas in which an engagement with the experience of totalitarianism is (or is not) taking place: intellectual circles and the Russian Orthodox Church. This distinction is not always sharp, because, as we shall see, intellectuals have at times been active participants in church life, and church members have taken part in philosophical and theological debates outside the Church. An analytical distinction is nevertheless needed, because it brings to the fore the different potentials of the Orthodox religious tradition. My focus here will lie on the intellectual tradition, the importance of which as a critical and innovative force within Orthodoxy is beyond question.

\section{The Orthodox Intellectual Tradition in the Soviet Period and in Postcommunist Russia}


Stoeckl, Kristina: "The lesson of the revolution in Russian émigré theology and contemporary Orthodox thought." Religion, State and Society 4 (2007), 285-300.

In the Soviet Union the heritage of the prerevolutionary religious philosophers and of the émigré theologians was largely silenced by the regime. Today's philosophers who seek to connect with the tradition of religious philosophy in Russia, like Sergei Khoruzhi (born 1941) and Vladimir Bibikhin (1938-2004), speak about 'a period of silence' or even about a 'break' (Bibikhin, 2003, pp. 157-168; Khoruzhi, 1994). However, despite the hostility of the Soviet regime towards religion, religious thought in the Soviet Union continued to develop. Sources for this development were on the one hand the living memory of the philosophy of the Silver Age and the religious commitment of members of the intelligentsia, and on the other hand impulses that came from outside the Soviet Union through tamizdat books and the study of contemporary western authors. The intellectual careers of Khoruzhi and Bibikhin are exemplary for the thought process that resulted from this interplay, and my analysis of contemporary Orthodox thought in Russia will therefore be largely guided by their perspectives. ${ }^{6}$

Let me first turn to what we can call 'continuity from within', the permanence of religious philosophy in the spirit of the Silver Age in the Soviet Union. The most prominent figures in the religious intelligentsia from the 1960s to the 1990s were certainly Aleksei Losev (1893-1988) and Sergej Averintsev (1937-2004), who can be considered to have provided an intellectual bridge between prerevolutionary religious philosophy and the late Soviet period when this philosophy was officially reappropriated. They managed to introduce their students to the thought of Solov'yev, Florensky, Bulgakov and others and to teach them the fundamentals of Orthodox theology in the guise of lectures on Byzantine literature and classical philosophy, inspiring those very people who are taking the stage of Orthodox thought in Russia today. ${ }^{7}$

Losev was a philosopher and a teacher of classical philosophy and aesthetics at the Moscow Pedagogical University. As a young man he had been acquainted with Pavel Florensky. Florensky and the writings of the Russian religious philosophers, mainly Solov'yev, had a profound impact on Losev's own works such as Dialektika mifa (The Dialectic of Myth) or Filosofiya imeni (The Philosophy of the Name). He also wrote the first biography of Solov'yev to be published in the early perestroika period. In his later years Losev recalled his encounters with Florensky as the last glimpse of a religious culture whose disappearance he had to witness. From these memories, recorded by 
Stoeckl, Kristina: "The lesson of the revolution in Russian émigré theology and contemporary Orthodox thought." Religion, State and Society 4 (2007), 285-300.

Bibikhin, Losev emerges as the surviving representative of religious philosophy on Russian soil who strove to keep its legacy alive in private lectures given to selected students and indirectly in his works on classical literature and aesthetics. At the same time, however, Losev cannot be considered a religious dissident, despite attempts by some of his current followers to turn him into one. Upon his return to Moscow in the 1940s after several years of forced labour on the infamous White Sea Canal and exile in the Russian provinces, Losev was able to get a teaching position at the Moscow Pedagogical University. In this position he knew, as commentators have been able to show, how to arrange himself with the ruling Marxist ideology and to promote his ideas relatively undisturbed (Nakhov, 1996; Prat, 2001).

Vladimir Bibikhin became a student of Losev in 1964 and maintained regular contacts and scholarly meetings with him until 1984. From 1970 to 1972 he worked as a secretary in Losev's home office. Being a student of Losev meant being granted access to the secluded life Losev was living as a scholar in his house on the Arbat and being admitted to a world of thought radically different from the ideologised humanities at Moscow State University. ${ }^{8}$ The conversations with Losev revolved around Plato and Aristotle, Hegel and Husserl, Solov'yev and Florensky, aesthetics, mysticism and Orthodoxy. Khoruzhi, who has interpreted Losev's work as the last stage of the Russian metaphysics of all-unity, calls Losev 'a rearguard soldier', a person who promoted his philosophy and religiosity in an utterly hostile environment. In an interesting observation on style, Khoruzhi writes that Losev continued the style characteristic of the Russian religious philosophers, the emotionally and mystically charged language of Florensky, Bulgakov and Frank, but that in Losev's writings, addressed to an outside that was hostile to his message, this style became aggressive, defensive, addressing the reader as an enemy (Khoruzhi, 1992).

Sergej Averintsev also worked on classical literature, but his interest lay mostly with Byzantine thought. His most important book is on early Byzantine literature, a text which has been described as 'in reality dealing with Patristics'. ${ }^{9}$ Averintsev's professional situation was different from Losev's, since he took the major steps of his career in the 1960s and 1970s, a period of relative liberty in the humanities. He was an influential teacher, whose lectures on Byzantine aesthetics took place in 'auditoria full as if for a 
Stoeckl, Kristina: "The lesson of the revolution in Russian émigré theology and contemporary Orthodox thought." Religion, State and Society 4 (2007), 285-300.

football match'. ${ }^{10}$ Averintsev was an active believer, but he was nevertheless elected a member of the Soviet Academy of Sciences, and in the last year of the Soviet Union he entered politics as a deputy to the Supreme Soviet. In his active church life, Averintsev associated himself with the liberal strand of Orthodoxy, being close to dissident priests like Aleksandr Men' and Georgi Kochetkov. Outside the Soviet Union, Averintsev was recognised as the leading Russian expert on Orthodox theology, and in 1995 and 1996 he was member of a group of Russian intellectuals who visited Pope John Paul II, a group which also included Khoruzhi. Averintsev considered himself a student of Losev, whom he addressed as 'father of our generation' on the occasion of Losev's $90^{\text {th }}$ birthday, but from Bibikhin's memoirs it also becomes clear that their relationship was not always free of jealousy and suspicion (Bibikhin, 2004a).

The work and lives of Losev and Averintsev are probably the clearest testimonies to the continuity of an academic and personal engagement with religion and theology during Soviet communism, and it is especially the scholarly aspect that distinguishes them from the continuity we find in the Russian Orthodox Church and among Orthodox believers. During the perestroika period, when the Soviet authorities became more lenient with regard to religion, Losev and Averintsev emerged as the undisputed authorities on Orthodox thought. The Russian Orthodox Church had been in such disarray for decades that theological teaching had basically ceased, and even the church authorities recognised that they had a lot to learn from the lay theologians. ${ }^{11}$

Losev and Averintsev stand for the continuity of religious thought in the Soviet Union and to some extent also within the limitations that the Soviet regime imposed on philosophy. They sought to continue what the Bolshevik revolution had interrupted and, in the case of Averintsev, to diffuse this inheritance in the West as well. Their importance as conservators is undisputed, but their relevance as innovators for the Orthodox intellectual tradition is less clear. I will therefore now turn to a second aspect which is of relevance for Orthodox thought in the Soviet Union: the reception of impulses coming from the West.

Until the end of the 1980s access to works on philosophy and theology from the West and from Russia's prerevolutionary past was restricted by the Soviet authorities. Books of that sort were kept in a special section in state libraries called the spetskhran 
Stoeckl, Kristina: "The lesson of the revolution in Russian émigré theology and contemporary Orthodox thought." Religion, State and Society 4 (2007), 285-300.

(from spetsial'noye khraneniye, 'special storage'). Khoruzhi recalls ${ }^{12}$ that during his student years in the 1960s everybody interested in philosophy was aware of these 'hidden treasures'. The study of the Russian religious philosophers of the Silver Age was almost imperative, and despite their forbidden nature and the difficulty of getting hold of their texts, these authors were read and discussed. At the same time, however, the subversive nature of the enterprise overrated a literature that was, in fact, rather dated. Khoruzhi, for example, writes in a reflection on the reception of prerevolutionary religious philosophy in the perestroika and postsoviet periods that in public consciousness the forbidden religious philosophy of the Silver Age and emigration acquired the status of a place where all answers to current problems - Russia's future, its place in Europe - were to be found if only one could get there. Once the literature was made accessible, however, it became apparent both that there were no ready-made answers, and also that these texts could not serve as an immediate inspiration for new creative solutions. They turned out to be too utopian, too optimistic and too far-fetched, according to Khoruzhi's judgment. Only what was sufficiently 'easy' and graspable found an immediate echo in the political and social sphere: nationalism, fundamentalism, Eurasian ideologies (Khoruzhi, 1999). This view is shared by Vladimir Bibikhin, who under the provocative title Revolutsiya malo chemu nauchila (The Revolution has Taught Little) writes that the reappropriation of the forbidden literature since the 1980s is repeating old mistakes. In particular he criticises a maze of empty phrases - kosmism, sofiologiya, sobornost' - which serve only as general indicators of a rejection of western rationalism and Catholicism (Bibikhin, 2003, pp.179-81). It is this critical attitude which makes thinkers like Khoruzhi and Bibikhin the intellectual heirs of the Vekhi authors, despite the fact that they have been profoundly critical of their works and legacy.

An important event in the study of prerevolutionary religious philosophy and the reception of western literature was the publication of the Bol'shaya sovetskaya filosofskaya entsiklopediya (Great Soviet Philosophical Encyclopaedia) in the 1960s. During our interview in 2005 Khoruzhi recalled that a group of like-minded scholars, including Averintsev, Bibikhin, Renata Gal'tseva and himself, got the chance to work on entries on Russian religious philosophy and on Christian mysticism, for example on Meister Eckhart and Nicholas of Cusa - an important source of ideas even though the 
Stoeckl, Kristina: "The lesson of the revolution in Russian émigré theology and contemporary Orthodox thought." Religion, State and Society 4 (2007), 285-300.

encyclopaedia entries had to be of a largely biographical and descriptive nature. Bibikhin also has fond recollections of this period. The last and most important volumes of the Philosophical Encyclopaedia, he writes, challenged the official ideology, and he quotes Averintsev as saying 'This was our own little crusade' (Bibikhin, 2003, p. 196).

Besides the encyclopaedia, there were other government-sponsored projects in which scholars would be employed on translating and preparing digests (sborniki) of western philosophy. Bibikhin recalls these projects both fondly and critically. On the one hand they offered an opportunity to read otherwise inaccessible literature and provided invaluable food for thought; on the other hand, especially when it came to the Russian religious thinkers, they seemed designed to shape the thinkers' ideas into an official canon that could be read in support of Russian nationalism and, as an anti-individualist philosophy, of communism. 'Those in power started to look for ideological alternatives to Marxism early', writes Bibikhin (2003, p.196). As early as 1973, political strategists were starting to consider Orthodox patriotism an easy way out of an ideological dead end. Especially with regard to an ideological underpinning for the Soviet army, the state organs busied themselves with the elaboration of ideological alternatives, and to this end employed even the 'homeland dissidents', as Bibikhin calls himself and his fellows (Bibikhin, 2003, p. 181). These scholars translated and reviewed spetskhran literature, their texts being published in a series imprinted DSP ('dlya sluzhebnogo pol'zovaniya', 'for administrative use'), in numbered and limited editions that would be carefully distributed among state officials. Since the authorities imagined that Orthodoxy could provide a particularly useful ideological background for patriotism, research in this field was intensified. Bibikhin recalls that at the end of the 1970s religion was a particularly well-financed part of the DSP series. These studies remained on a superficial, ideologically correct level, he writes - a level which merely reflected the parlous state of religion in the country as a whole (Bibikhin, 2003, p. 193).

As well as Orthodox writers, however, western authors were also translated and reviewed. Kierkegaard, Karl Barth, Paul Tillich and Dietrich Bonhoeffer were translated for a publication on contemporary Protestantism. In 1974 Bibikhin began to translate Heidegger, and together with his colleagues he also worked on Merleau-Ponty, Ortega y Gasset, Sartre and Wittgenstein. In 1976 key authors in European structuralism and 
Stoeckl, Kristina: "The lesson of the revolution in Russian émigré theology and contemporary Orthodox thought." Religion, State and Society 4 (2007), 285-300.

poststructuralism, Umberto Eco and Jacques Derrida, were translated. ${ }^{13}$

The employees of the Department for Scientific Information and Study of Foreign Philosophical Literature (Sektor nauchnoi informatsii i referirovaniya zarubezhnoi filosofskoi literatury) of the Soviet Academy of Sciences prepared digests of western philosophy and social science that would then be studied and commented upon by 'official' scholars. Bibikhin recalls that the translators were painfully aware that they were not writing for a reading public, and that, above all, they were working years behind the scholars in the West. 'When Heidegger was finally published,' Bibikhin writes, 'deconstructivism was already in full swing in the West' (Bibikhin, 2003, p. 188). Bibikhin evaluates the longerterm effect of these activities critically. In his opinion, the texts were too fragmented, were chosen from too particular a perspective, and could hardly serve as a solid basis for the reception of western thought once this was no longer a forbidden field. On the other hand, he writes that the work for the department opened up a window to the West, especially for those who would not otherwise have got permission to travel to the West, or for those who, 'if they happened to be allowed on a two-week trip to Paris', realised only more deeply how insufficient such a short glimpse was (Bibikhin, 2003, p. 205).

Bibikhin's memoirs make clear how immensely important access to the human and social sciences in the West was for those scholars working in the Soviet Union who found themselves at the margins of the official Marxist-Leninist canon. It provided them with an outside perspective on their own situation as scholars, on the absurdity of being confined to a closed library, working for a non-public, not even allowed to take home their translations and papers. ${ }^{14}$ It seems legitimate to assume that for most of the people involved in these projects, such a glimpse of the outside world would not only confirm their critical stance towards the Soviet human and social sciences, but that it would also shed new light on the habitual canons of dissident literature. Khoruzhi remembers that the first food for thought for anyone interested in philosophy were, by default, the works of the philosophers of the Silver Age: the DSP papers therefore certainly pointed towards a much larger horizon.

Besides western literature, those interested in Orthodox thought received the important input of Russian émigré theology. During our interview Khoruzhi recalled how he first found out about the latest developments in this field. In the early 1970s he came 
Stoeckl, Kristina: "The lesson of the revolution in Russian émigré theology and contemporary Orthodox thought." Religion, State and Society 4 (2007), 285-300.

across John Meyendorff's doctoral thesis on Gregory Palamas. The book was in French and had somehow passed the censorship for religious literature unnoticed. Unlike other literature of the genre it was not kept in the spetskhran but could simply be ordered from the librarian. Khoruzhi told me that he was intrigued by this 'new way' of philosophical and theological reflection. He consequently concentrated his studies on the Church Fathers, on Hesychasm, and especially on Palamas.

Neo-Palamism started as a phenomenon of the Russian émigré theology and it reached the Soviet Union only in small doses. It belongs to Neopatristic theology and is distinguished by the emphasis it puts on the theological distinction between divine essence and divine energies, elaborated by Gregorios Palamas in the fourteenth century. (Meyendorff, 1998, pp.82-92). Besides Meyendorff, Vladimir Lossky was a central author. The theologian Nikolai Gavryushin has recently recalled a striking episode in patristic scholarship in Russia. In late 1972, he writes, the Moscow intelligentsia was undertaking a particular kind of pilgrimage to the Novodevichi Monastery where the publishing house of the Moscow Patriarchate was located. There, in the office of the editor-in-chief, one could find the eighth volume of Bogoslovskiye trudy. It was dedicated to the work of Vladimir Lossky - 'at that period,' Gavryushin writes, 'an epochal event' (Gavryushin, 2005a). Like the work of Meyendorff, the theology of Lossky represented an exposition of Orthodox doctrine that was at one and the same time scholarly and religiously convincing and that marked a change from the religious language of the nineteenth century. Especially Lossky's elaboration of the notion of the person can be read as a direct response to the overemphasis on the collective in Orthodox thought.

In the 1990s, Khoruzhi emerged as a prolific scholar of theology, philosophy and history of religious thought, his interest ranging from prerevolutionary Russian religious philosophy to the theology of the Church Fathers to modern and postmodern western philosophy. The works in which he covers this wide range of topics were published over a few years from 1991; but they testify to decades of intellectual engagement during which Khoruzhi developed his theological and philosophical position while working as a mathematician and physicist in the Soviet Union. ${ }^{15}$ The work of those years remained largely unpublished and is only now available to a wide readership. During our interview, Khoruzhi himself described his philosophical career as a moving away from the 
Stoeckl, Kristina: "The lesson of the revolution in Russian émigré theology and contemporary Orthodox thought." Religion, State and Society 4 (2007), 285-300.

'methodological sloppiness' of the prerevolutionary religious philosophers to the theological rigour of the Neopatristic theologians which he then sought to translate into his personal philosophical language of 'synergetic anthropology'.

Khoruzhi's work testifies to this self-understanding. He has written extensively about Russian religious philosophers, notably Solov'yev, Florensky, Karsavin and Bulgakov. He takes a critical approach to the legacy of these authors. In his eyes they do not have much to offer to contemporary philosophy, and he is therefore dismissive of the attempts by some of his contemporaries to revive them (Khoruzhi, 1991, 1999). In an article with a particular history, he is very clear on this issue. In this article he recalls how in the late perestroika years he suddenly found himself involved in the activities of the ideologists. In 1988, he writes, in the course of negotiations about the publication of essays by Lev Karsavin with an official publishing house, he was asked to write a review of a study entitled Krusheniye russkogo idealizma (The Collapse of Russian Idealism), a piece by, as he puts it, 'a bureaucratic fighter on the ideological front'. Hoping that this would further the publication of Karsavin (which it eventually did not), he agreed to write the review. In 1994 he published it as an article with the title $O$ maroderakh (The Looters), now in order to protest against the superficial reappropriation of the religious philosophers: 'Today the fighters have rather successfully developed new forms of looting, having become fierce apologists for Russian thought' (Koruzhi, 1994, p. 254). The main point of his criticism, put forward with a remarkable degree of irony, is the fact that communist ideologues turned themselves into Christian thinkers. It was a very strong gesture for Khoruzhi to publish this piece in 1994, and to many who cherished the legacy of the Silver Age it must have appeared an affront. Its publication only underlines, however, how decisively Khoruzhi had broken with the canon of Russian religious philosophy, a step induced by his discovery of Neo-Palamism as laid out in more or less all his works. In a long essay about the émigré philosophy and theology of the 1920s and 1930s, Shag vpered, sdelanny v rasseyanii (A Step Forward, Taken in Dispersal), Khoruzhi makes it clear that for him the main intellectual achievement of the Russian diaspora was in the field of theology (Khoruzhi, 2005a, pp. 335-445). In his view, Neopatristic theology offers a new paradigm for religious thought which is not conservative, but based on the idea of creative tradition. ${ }^{16}$ 
Stoeckl, Kristina: "The lesson of the revolution in Russian émigré theology and contemporary Orthodox thought." Religion, State and Society 4 (2007), 285-300.

Khoruzhi credits the Neopatristic theologians with having changed the orientation of Orthodox thought. Their reappraisal of the dogmatic foundations of Orthodoxy, especially the emphasis on Palamism, has opened up an entirely new field of thought which can also be made productive philosophically. It seems that, almost as a matter of such preparation, a large part of Khoruzhi's work is dedicated to the notions of hesychasm and asceticism (Khoruzhi, 1998, 2005b). The Neo-Palamist theologians effected a turn for Orthodox thought which Khoruzhij, with reference to Heidegger, calls a Kehre, a (re-)turn, or a 'modulation of the discourse' (Khoruzhi, 2005a, p. 28). However, this turn was a theological, not a philosophical phenomenon, Khoruzhi writes, and when this thought could finally make its way back to Russia after the fall of communism, its philosophical potential had not yet been explored. ${ }^{17}$ To do this is exactly the task which Khoruzhi sets himself: 'Russian philosophy stands in front of a new beginning,' he writes - a new beginning that implies a rethinking of the relationship between theology and philosophy as it has been manifest in classical metaphysics (Khoruzhi, 2005a, p. 29). The elaboration of an anthropology that would overcome the limitations imposed by western metaphysics is Khoruzhi's philosophical project, and herein he sees the similarities of his work to western postmodern philosophy, especially to Deleuze and Foucault.

While Khoruzhi emerged as the most important new scholar of Orthodoxy in the 1990s, Vladimir Bibikhin, despite his close connection with Losev and Averintsev over several decades, remained largely outside of the field of religious philosophy. In the 1980s Bibikhin was already suspicious about the religious renewal under state tutelage. In 1985 he broke with his former teacher Losev over an interview the latter gave to the newspaper Pravda ${ }^{18}$, and in an essay of 1989 he criticises the political use which was being made of the Russian religious philosophers by the rival circles of 'patriots' and 'cosmopolitans' (Bibikhin, 2003, pp. 208-26). The books he published after the fall of communism were predominantly philosophical. Yazyk filosofii (The Language of Philosophy) (1993) was followed by a number of publications, some of them based on lectures given in the philosophy department at Moscow State University: Uznai sebya (Know Yourself) (1998), Novy Renessans (The New Renaissance) (1998), and Vitgenshtein (Wittgenstein) (2004). A translator by training, he translated and commented 
Stoeckl, Kristina: "The lesson of the revolution in Russian émigré theology and contemporary Orthodox thought." Religion, State and Society 4 (2007), 285-300.

on Heidegger and contemporary French philosophers but also Nicholas of Cusa, Gregory Palamas, Dionysios the Aeropagite and many others. He also wrote theological essays, some of which have appeared abroad (Bibikhin, 1992, 1995, 1999, 2001, 2002, 2004c). To what extent his philosophical pursuit in the last decade and a half of his life was determined by religious motives is difficult for me to judge at this point; further research is needed here. ${ }^{19}$ What is clear is that in his notes on Averintsev, which often acquire the character of a personal diary, Bibikhin admits that he cannot share the pure religiosity of his friend; nor did the theology of Palamas seize him in any profound manner. It is also important to note that Bibikhin did not make as close a link between his studies of phenomenology, linguistics and French philosophy and his studies of Orthodox theology as his friend Khoruzhi, who includes western philosophers in his theological studies, or as the Greek theologian Christos Yannaras, who draws on Heidegger for an elaboration of the Palamitian concept of energies.

For an understanding of the dynamics of contemporary Orthodox thought, Bibikhin is undoubtedly an important and interesting figure. Steeped in the philosophical world of Losev like hardly anyone else; a close friend of Averintsev; the husband of Renata Gal'tseva, another prominent member of the religious intelligentsia; working as a translator and therefore acutely aware of impulses coming from abroad; and having a highly critical and suspicious attitude concerning any kind of ideologisation and political instrumentalisation of philosophical thought: Bibikhin appears to have found the Orthodox pathway to a philosophical response to the social, political and intellectual upheaval of the postcommunist transition implausible. He categorically rejected any nostalgia for prerevolutionary Russian religious philosophy and on these grounds opposed those who were turning Losev into a saint-like figure of religious resistance. ${ }^{20}$ At the same time, it seems that, unlike his friend Khoruzhi, he did not find the impulses coming from émigré theology sufficient or convincing for a different kind of religious philosophy. If, as a consequence, he largely withdrew from the religious thinking of the 1990s, then we should consider this an important and sincere gesture, a possible standpoint to take in the face of the Orthodox confrontation with its own totalitarian potential. $^{21}$

In conclusion to these observations about the Orthodox intellectual tradition, I 
Stoeckl, Kristina: "The lesson of the revolution in Russian émigré theology and contemporary Orthodox thought." Religion, State and Society 4 (2007), 285-300.

suggest that we can find in the late Soviet and postsoviet era a continuation of the critical engagement with the Orthodox tradition that sets in with the experience of totalitarianism. With reference to Valliere's useful distinction, we see that the spirit of the Russian School theologians did prevail among those intellectuals who, like Averintsev, sought to combine their philosophical and theological work and their personal religiosity with an active engagement in society and in politics. In contrast to this attitude, we find that Khoruzhi has taken aboard the position of the Neo-Palamist theologians, which implies a profoundly critical attitude towards the philosophy of the Silver Age and a philosophical and ontological inquiry into the meaning of the human subject and of the transcendent. Without taking these topics further at this point, I shall now complete my observations on Orthodox thought in the twentieth century with a very brief analysis of the situation of the Russian Orthodox Church in postcommunist Russia, before giving, in my conclusion, an overall interpretation of the 'lessons of the revolution' for Russian Orthodoxy.

\section{The Russian Orthodox Church and Orthodox Fundamentalism in Postcommunist Russia}

The Russian Orthodox Church (ROC) met the collapse of the Soviet Union in 1991 from a position of ambiguity. On the one hand, the collapse signified the downfall of a regime which had been the source of suppression for decades; on the other hand, the ROC had been very successful in strengthening its position during the political developments of the perestroika period. ${ }^{22}$ The official celebration of the millennium of the christianisation of Rus' with the participation of Gorbachev in 1988 is just one example of the special status which the ROC had acquired. One could say that the ROC has successfully held on to this status ever since. The open question, however, is on what grounds the ROC is defining its place in Russian society. Where does the ROC stand with regard to the experience of totalitarianism?

I shall argue that we find in the ROC an official discourse of modernisation and individual liberty which exists in parallel with a fundamentalist, antimodern and antiindividualist discourse. While the former represents the ROC to the world at large, the 
Stoeckl, Kristina: "The lesson of the revolution in Russian émigré theology and contemporary Orthodox thought." Religion, State and Society 4 (2007), 285-300.

latter seems to dominate the role of Orthodoxy in Russian society. The best example of the former, modernising discourse is the document issued by the ROC in 2000, The Bases of the Social Concept for the Russian Orthodox Church. This document lays out the Russian Orthodox Church's position on a variety of socio-cultural phenomena, encompassing a whole range of issues from state and law to secularism, from culture to bioethics. The mere existence of the text suggests that the view that the ROC should modernise itself, that it should no longer remain in a position of rejection of modernity and instead take a stand on contemporary problems, has been gaining ground among Orthodox theologians. ${ }^{23}$ It has been pointed out that the Social Doctrine is above all a carefully weighted document which tries to steer between extreme conservatism and radical reformism, and the fact that it won the support of both conservative and liberal forces in the Russian Church testifies to this (Agadjanian, 2003a, 2003b). It takes a pragmatic stance on contemporary problems and introduces a moderately liberal and modernising tone while in substance maintaining a critical-conservative attitude.

What is interesting for us to note, however, is that the document deals only indirectly with the 'lessons' of totalitarianism. We do find in the document a clear declaration of the separation of state and church and a denunciation of political engagement by the ROC and of its political instrumentalisation. What we do not find, however, is a critical discussion of the autocratic legacy of Orthodox tsardom that furthered the fateful entanglement of church with state ideology during Stalinism. The notion of sobornost' provides a good example for this failure to engage critically with Orthodoxy's own intellectual heritage. Writing about community, the authors of the document refer to the concept of sobornost' in a definition by its nineteenth-century creator Aleksei Khomyakov. They thus refer to the concept in its original form, without engaging in a debate about its history and problematic usage in antiwestern and Russian nationalist ideologies. The failure to discuss critically the notion of sobornost' is even more striking given the fact that such a critical discussion is, as I have shown, readily available in the writings of the Russian émigré theologians.

In contrast to the modernising tone of much the official writing of the Moscow Patriarchate, Orthodox fundamentalism professes a profoundly antiwestern and antimodern ideology. The experience of totalitarianism is not taken as a lesson, it is rather 
Stoeckl, Kristina: "The lesson of the revolution in Russian émigré theology and contemporary Orthodox thought." Religion, State and Society 4 (2007), 285-300.

taken as a model! In the writings of Metropolitan Ioann (Snichev) of St Petersburg and Ladoga, the late spokesperson of the Orthodox fundamentalists, we find no critical revision of Slavophile prerevolutionary thought or of church subservience to the autocratic state, and the concept of sobornost' serves to justify the suppression of individual rights (Verkhovsky, 2002; Kostyuk, 2000). It has to be noted that the Moscow Patriarchate has been cautious, distancing itself from overtly fundamentalist positions. However, as Kostyuk has pointed out, Orthodox fundamentalism is strong in contemporary Russia, prepared for by the ideologisation and nationalisation of the Orthodox religion which had already taken place during the Soviet period (Brudny, 1998). It has taken hold not only of the lives of many people, but also of scholarship, politics, and, most problematically, education. ${ }^{24}$ In today's Moscow an Orthodox fundamentalist and antisemitic painter, Il'ya Glazunov, has moved to the highest ranks of public esteem, with his own museum in the centre of the city and the best connections to Moscow's mayor Luzhkov and the Kremlin. The findings about Orthodox fundamentalism are alarming, because they testify to the fact that a nationalist and cultural chauvinist way of thinking is gaining ground in Russia. It is gaining ground in society as such, and it is not necessarily a religious phenomenon. ${ }^{25}$

\section{Conclusion}

In this article I have mapped different trajectories of Orthodox thought in the twentieth century. This task seems especially salient at a point in time when in an atmosphere of political, social and intellectual renewal in postcommunist Orthodox Eastern Europe different trends from the history of Orthodox thought are being revived, including Slavophile and Eurasian ideologies, the religious philosophy of the Silver Age, Patristic theology, and the debates from émigré theology. I have cut across the whole spectrum of Orthodox thought in Russia today, both clerical and lay, both theological and philosophical, in order to show the different ways in which the Orthodox intellectual tradition has reacted to the experience of totalitarianism. Many representatives of Russian Orthodoxy - and most casual western observers - overlook what Bulgakov and Bibikhin have called 'the lesson taught by the revolution'. This lesson is expressed in the need to 
Stoeckl, Kristina: "The lesson of the revolution in Russian émigré theology and contemporary Orthodox thought." Religion, State and Society 4 (2007), 285-300.

formulate clear standpoints on the totalitarian challenge from within the Orthodox theological tradition. Russian émigré theology and its contemporary heirs have embarked upon this path; the Russian Orthodox Church has not, or to a much lesser extent.

The Orthodox confrontation with its own totalitarian potential is in many ways comparable to western responses to totalitarianism. In the West, philosophers reacted to the experience of totalitarianism either with attempts to strengthen the liberalindividualist paradigm or with a deconstruction of it, in both cases the aim being to devise a safely post-totalitarian social and political philosophy. It seems to me that the Orthodox thinkers described in this paper do something very similar. Post-totalitarian Orthodox thought is conscious of the totalitarian potential inherent in cultural and religious fundamentalism and it shares the critique of political modernism in the West. I interpret the programmes of theological and intellectual renewal by the Vekhi authors and Russian School theologians on the one hand and by Neopatristic theologians on the other hand as two ways of facing the challenge of totalitarianism, the first comparable to the liberal response in the West insofar as it seeks to strengthen a social and communitarian ideal in modern society, the second comparable to postmodernism inasmuch as it welcomes the deconstruction of classical metaphysics and finds in Palamitian theology an alternative ontology. Both schools have found a continuation in contemporary Orthodox thought, and it is this philosophical tradition within Orthodoxy that has the potential to mark an opening where, at least in Russia, the Orthodox Church remains oblivious to the lesson of the revolution.

\section{References}

Agadjanian, A. (2003a) 'Breakthrough to modernity, apologia for traditionalism: the Russian Orthodox view of society and culture in comparative perspective', Religion, State \& Society, 31, 4, pp. 327-46.

Agadjanian, A. (2003b) 'The social vision of Russian Orthodoxy: balancing between identity and relevance', in J. Sutton and W. van den Bercken (eds.), Orthodox Christianity and Contemporary Europe (Leuven/Paris/Dudley, Peeters), pp.163-82. Agadzhanyan, A. (2000) 'Religiozny diskurs v rossiiskikh mass-media: entropiya, 
Stoeckl, Kristina: "The lesson of the revolution in Russian émigré theology and contemporary Orthodox thought." Religion, State and Society 4 (2007), 285-300.

simfoniya, ideokratiya', in K. Kaariainen and D. Furman, D. (eds.), Staryye tserkvi, novyye veruyushchiye: religiya v massovom soznanii postsovetskoi Rossii (Moscow/St

Petersburg, Letni sad).

Arendt, H. (2004) The Origins of Totalitarianism (New York, Schocken Books).

Berdyaev, N. (1960) The Origin of Russian Communism (Michigan, Ann Arbor Paperback, University of Michigan Press).

Bibikhin, V. V. (1992) 'Filosofiya i religiya', Voprosy filosofii, 7, pp.34-44.

Bibikhin, V. V. (1993) Yazyk filosofii (Moscow, Progress).

Bibikhin, V. V. (1995) 'Materialy k isikhastskim sporam', in S.S. Khoruzhi (ed.),

Sinergiya: problemy asketiki i mistiki pravoslaviya (Moscow, Di-Dik).

Bibikhin, V. V. (1998a) Novy Renessans (Moscow, Nauka/Progress-Traditsiya).

Bibikhin, V. V. (1998b) Uznai sebya (St Petersburg, Nauka).

Bibikhin, V. V. (1999) 'Dveri zhizni', in A.F. Losev (ed.), Lichnost' i absolyut (Moscow, Mysl').

Bibikhin, V. V. (2001a) 'K vizantiiskoi antropologii', Tochki-Puncta, 3-4, pp. 21-40.

Bibikhin, V. (2001b) 'L'unità della fede', La Nuova Europa, 1, pp. 4-12.

Bibikhin, V. (2002) 'La Chiesa militante', La Nuova Europa, 6, pp. 4-18.

Bibikhin, V. V. (2003) Drugoye nachalo (St Petersburg, Nauka).

Bibikhin, V. V. (2004a) Aleksei Fedorovich Losev, Sergei Sergeyevich Averintsev

(Moscow, Institut filosofii, teologii i istorii Sv. Fomy).

Bibikhin, V. V. (2004b) Vitgenshtein: smena aspekta (Moskva, Institut filosofii, teologii i istorii Sv. Fomy).

Bibikhin, V. V. (2004c) Pravoslavie i vlast', http://www.polit.ru/research/2004/12/14/bibikhin.html (accessed 10 January 2005).

Bird, R. (2003) 'The tragedy of Russian religious philosophy: Sergi Bulgakov and the future of Orthodox theology', in J. Sutton and W. van den Bercken (eds.), Orthodox Christianity and Contemporary Europe (Leuven/Paris/Dudley, Peeters), pp.211-28.

Brudny, Y. M. (1998) Reinventing Russia: Russian Nationalism and the Soviet State, 1953-1991 (Cambridge, MA/London, Harvard University Press).

Bulgakov, S. (1999) Towards a Russian Political Theology (edited by R.Williams) (Edinburgh, T\&T Clark). 
Stoeckl, Kristina: "The lesson of the revolution in Russian émigré theology and contemporary Orthodox thought." Religion, State and Society 4 (2007), 285-300.

Filatov, S. B. (2002) Religiya i obshchestvo: ocherki religioznoi zhizni sovremennoi Rossii (Moscow/St Petersburg, Letni sad).

Florovsky, G. (1987) The Ways of Russian Theology (The Collected Works of Georges Florovsky, vols. 5-6) (Belmont, MA/Vaduz, Nordland Publishing Company/ Büchervertriebsanstalt).

Foucault, M. (1984) 'What is Enlightenment?', in P. Rabinow (ed.), The Foucault Reader (New York, Pantheon Books).

Gavryushin, N. (2004) 'Istinnoye bogosloviye preobrazhayet metafiziku: zametki o Vladimire Losskom', Simvol, 48, pp. 164-216.

Gavryushin, N. (2005b) 'Pamyati Vladimira Veniaminovicha Bibikhina', Stranitsy, 4, pp.625-26.

Habermas, J. (1981) Theorie des kommunikativen Handelns (2 vols) (Frankfurt a. M., Suhrkamp).

Heller, A. (1999) A Theory of Modernity (Malden, MA, Blackwell).

Kaariainen, K. and Furman, D. (1997) 'Veruyushchiye, ateisty i prochiye (evolyutsiya rossiiskoi religioznosti', Voprocy filosofii, 6, pp. 35-52.

Khoruzhi, S. S. (1991) 'Filosofsky protsess v Rossii kak vstrecha filosofii i pravoslaviya', Voprosy filosofii, 5, pp.26-57.

Khoruzhi, S. S. (1992) 'Ar"yergardny boi: mysl' i mif Alekseya Loseva', Voprosy filosofii, 10, pp.112-38.

Khoruzhi, S. S. (1994) Posle pereryva: puti russkoi filosofii (St Petersburg, Aleteya).

Khoruzhi, S. S. (1998) K fenomenologii askezy (Moscow, Izdatel'stvo gumanitarnoi literatury).

Khoruzhi, S. S. (1999) 'Putem zerna: russkaya religioznaya filosofiya segodnya, Voprosy filosofii, 9, pp.139-47.

Khoruzhi, S. S. (2005a) Opyty iz russkoi dukhovnoi traditsii (Moscow, Parad).

Khoruzhi, S. S. (2005b) Ocherki sinergiinoi antropologii (Moscow, Institut filosofii, teologii i istorii Sv. Fomy).

Kostjuk, K. (2005) Der Begriff des Politischen in der russisch-orthodoxen Tradition (Paderborn/München, Schöningh).

Kostyuk, K. N. (2000) 'Pravoslavny fundamentalism', Polis, 5, pp.133-54. 
Stoeckl, Kristina: "The lesson of the revolution in Russian émigré theology and contemporary Orthodox thought." Religion, State and Society 4 (2007), 285-300.

Lefort, C. (1986) 'The logic of totalitarianism', in J.B. Thompson (ed.), The Political Forms of Modern Society: Bureaucracy, Democracy, Totalitarianism (Cambridge/Oxford, Polity Press).

Lefort, C. (1988) 'The permanence of the theologico-political?' in C. Lefort, Democracy and Political Theory (Cambridge/Oxford, Polity Press).

Lotman, Y. M. and Uspensky, B. A. (1977) 'Rol' dual'nykh modelei v dinamike russkoi kul'tury (do kontsa 18-ogo veka)', in V. I. Bessubov (ed.), Trudy po russkoj i slavyanskoj filologij Vol. XXVIII (Tartu, Uchen. zap. Tartuskogo gos. un-ta; vyp. 414).

Nakhov, I. (1996) 'Losev and Marxism: lessons of a life, 1893-1988', Russian Studies in Philosophy, 35, pp.70-85.

Makrides, V. N. and Uffelmann, D. (2003) 'Studying Eastern Orthodox anti-westernism: the need for a comparative research agenda', in J. Sutton and W. van den Bercken (eds.), Orthodox Christianity and Contemporary Europe (Leuven/Paris/Dudley, Peeters), pp.87120.

Prat, N. (2001) 'Losev i totalitarizm', Voprosy filosofii, 5, pp.78-84.

Rawls, J. (1973) A Theory of Justice (Oxford, Oxford University Press).

Scherrer, J. (2003) Kulturologie: Rußland auf der Suche nach einer zivilisatorischen Identität (Göttingen, Wallstein).

Schmemann, A. (1972) 'Russian Theology 1920-1972: an introductory survey', St Vladimir's Theological Quarterly, 16, pp.172-94.

Shatz, M. S. and Zimmermann, J. E. (eds.) (1994) Vekhi: Landmarks: a collection of articles about the Russian intelligentsia (Armonk, NY, M. E. Sharpe).

Stoeckl, K. (2006) 'Modernity and its critique in twentieth century Russian Orthodox thought', Studies in East European Thought, 58, pp.243-69.

Sutton, J. (2002) A 'Religious Intelligentsia' in Present-Day Russia? Towards Responsibility and Engaged Reflection (unpublished manuscript) (paper presented at the conference 'The Intelligentsia of Russia and Poland: the Intelligentsia as Creators of Social Values', University of Lund, 22-24 August 2002).

Talmon, J. L. (1963) Politischer Messianismus: die romantische Phase (Köln/Opladen, Westdeutscher Verlag).

Talmon, J. L. (1986) The Origins of Totalitarian Democracy (Middlesex, NY, Penguin 
Stoeckl, Kristina: "The lesson of the revolution in Russian émigré theology and contemporary Orthodox thought." Religion, State and Society 4 (2007), 285-300.

Books).

Valliere, P. (2000) Modern Russian Theology: Bukharev, Soloviev, Bulgakov: Orthodox Theology in a New Key (Edinburgh, T\&T Clark).

Valliere, P. (2001) 'Russian religious thought and the future of Orthodox theology', St Vladimir's Theological Quarterly, 45, pp.227-41.

Verkhovsky, A. (2002) 'The role of the Russian Orthodox Church in nationalist, xenophobic and antiwestern tendencies in Russia today: not nationalism, but fundamentalism', Religion, State \& Society, 30, pp.333-45.

Wagner, P. (1994) A Sociology of Modernity: Liberty and Discipline (London/New York, Routledge).

\section{Notes}

1 Another scholar who has forcefully put forward the argument that totalitarianism was a sign of a crisis of the modern consciousness is Hannah Arendt (Arendt, 2004).

2 Berdyayev explains Soviet communism with reference to the legacy of Orthodox tsardom (Berdyaev, 1960, p.169). Talmon, for example, despite his insightful study of the modern dimension of totalitarianism, characterises Russia as nonwestern and as not possessing the category of the individual. He considers Russian communism a means to maintain the specificity of the Russian nation (Talmon, 1963, $\mathrm{p}$. 469).

3 Sobornost' is in fact one of the terms that is revisited by émigré theologians and contemporary authors in order to distinguish between its theological meaning and its socio-political use and abuse. The work of Vladimir Lossky is exemplary in this respect. Lossky was critical of anything that stemmed from the Slavophile period in Russian thought, to the extent that Williams even speaks about 'Lossky's intellectual allergy to the language of sobornost" (Bulgakov, 1999, p. 176). Lossky's acute awareness of the risk that the theological notion of sobornost' may be abused as a crude socio-political concept certainly played a role in his subsequent elaboration of Orthodox ecclesiology.

I have described the debates in Russian émigré theology in more detail in my article 'Modernity and its critique in twentieth century Russian Orthodox thought' (Stoeckl, 2006).

5 The following quote from Florovsky is unequivocal on this point: 'Russian theology must confidently penetrate the entire complex problematics of western religious thought and spiritually trace and examine the difficult and bewildering path of the West from the time of the Great Schism. Access to the inner creative life comes only through its problematics, and one must therefore sympathize with that life and experience it precisely in its full problematicality, searching and anxiety. Orthodox theology can recover its independence from western influence only through a spiritual return to its patristic sources and foundations. Returning to the fathers, however, does not mean abandoning the present age, escaping from history, or quitting the field of battle. Patristic experience must not only be preserved, but it must be discovered and brought into life. Independence from the non-Orthodox West need not become estrangement from it. A break with the West would provide no real liberation. Orthodox thought must perceive and suffer the western trials and temptations, and, for its own sake, it cannot afford to avoid and keep silent over them.' (Italics mine - KS) (Florovsky, 1987, p. 301).

6 Bibikhin's perspective is documented in notebook entries published shortly before his death (Bibikhin, 2004a); Khoruzhi's is expressed during our conversation in the summer of 2005 and in several of his essays.

7 No complete study of the role of these two scholars is yet available, but it is indicative of their 
Stoeckl, Kristina: "The lesson of the revolution in Russian émigré theology and contemporary Orthodox thought." Religion, State and Society 4 (2007), 285-300.

shared importance for the permanence of religious philosophy during the Soviet period that Bibikhin, who was Losev's trusted student and secretary and Averintsev's close friend, brings them together in a publication of notes taken during conversations with them over the course of several decades: Bibikhin, 2004a.

$8 \quad$ The following recollection by Bibikhin is worth quoting in full, because it conveys particularly well the atmosphere of the meetings with Losev: 'When I walked down the Arbat towards the centre after my first lesson with Aleksei Fedorovich, I had become a different person. The city had changed, the air was rich, the space around me was deep. I could move easily in this new density. Every time I approached Losev's house, the Arbat began to appear particularly empty, the people around me very agitated. The room on the second floor with the window to the courtyard spoke of strict reclusion from the world. Here people thought. A big man in an imposing armchair among books stacked on the table and in the former fireplace kept vigil in silent contemplation. "Good evening, Vladimir".' (Bibikhin, 2004a, p. 11).

$9 \quad$ By an acquaintance of Averintsev during our conversation in Moscow on 17 June 2005.

10 Recollection of a former colleague of Averintsev during our conversation in Moscow on 16 June 2005 .

11 View expressed by a deacon of the Moscow Patriarchate during our conversation in Moscow on 21 June 2005.

12 During our interview in Moscow on 15 June 2005.

13 Bibikhin cites these texts as various volumes published under the rubric 'dlya sluzhebnogo pol'zovaniya' in Moscow by the Institut filosofii AN SSSR, sektor nauchnoi informatsii i referirovaniya zarubezhnoi filosofskoi literatury. Titles included: Sovremenny protestantizm (1973); Dialektika Gegelya $v$ otsenke sovremennykh zapadnykh filosofov (1974); Ontologicheskaya problematika yazyka v sovremennoi zapadnoi filosofii (1975), Filosofiya Kanta i sovremennost' (1976); Nekotoryye problemy zarubezhnoi estetiki (1976); Sovremennaya fenomenologiya: sostoyaniye i perspektivy (kritichesky analiz) (1977); Sovremenny personalizm i religiya (1977).

$14 \quad$ Making DSP literature available outside the controlled circulation was a criminal offence and Bibikhin writes that up to the year 2001 he felt haunted by the fear that he could be held accountable for the possession of DSP material (Bibikhin, 2003, p. 189).

15 Jonathan Sutton (2002) has pointed out that for many young intellectuals the pursuit of scientific and technological studies in the Soviet Union was a common escape-route from the ideologised humanities and social science faculties; Khoruzhi's career is a case in point.

16 During our interview Khoruzhij took issue with Valliere's characterisation of the Neopatristic thinkers as traditionalists and conservatives. Following the tradition of the Fathers, he insists, is not a conservative principle, but a creative one.

17 This estimate by Khoruzhi is true for the Russian case, but it is not true for Greece, where Christos Yannaras did engage philosophically with Neo-Palamism as early as 1970.

${ }_{18} \quad$ Let me quote part of a letter which Bibikhin wrote to Aleksej Losev and his wife Aza Takho-Godi on 23 January 1985, and which he reproduces in his book, because it conveys his disappointment with his former teacher over what he had considered a common struggle against the ideologisation of the humanities: 'Thank you for your "Epiphany epistle". I had not seen this copy of Pravda with the interview with Aleksei Fedorovich before, but I had heard a lot of talk about it. Of course, instead of naming Lunacharsky as an example of "an outstanding lecturer" one could have cited Fedor Stepun, and instead of "the mad excesses of bourgeois-capitalist civilisation" one might simply have simply said "technological civilisation": the censor would have had no problem allowing that. As for "materialist understanding of history" and "class enemy", these are also extra titbits thrown to the guard dogs, like overfeeding those who are already full. But on the whole, this is probably the first time that a paper for so many million readers has published such powerful and positive words by such a genial thinker.' (Bibikhin, 2004a, pp. 293-94). ${ }_{19}$ Gavryushin even speaks about a 'break' in Bibikhin's thinking (Gavryushin, 2005b, pp. 625-26). I also find it indicative that among philosophy students of the early 2000 s whom I had the chance to meet Bibikhin's connection to the religious intelligentsia was little known and apparently considered barely relevant.

20 This becomes clear from his reflections on the adaptation of Losev's house as a museum and centre for the study of Russian religious philosophy (Bibikhin, 2004a, pp.299-302) 
Stoeckl, Kristina: "The lesson of the revolution in Russian émigré theology and contemporary Orthodox thought." Religion, State and Society 4 (2007), 285-300.

21 Sadly, Bibikhin died in 2004. Some of his work remains unpublished so far, and it is a pity that during his lifetime several large volumes were published without having been properly edited, lacking tables of contents and indices. Any judgment on his work thus has to be preliminary.

22 The close allegiance of the ROC to the authorities manoeuvred the religious hierarchy into an increasing alienation from lay believers. The case of the priest Aleksandr Men' is exemplary in this respect: Men' (1935-90) was an Orthodox priest of Jewish origin. A charismatic and unconventional figure with many followers, he was murdered under unclear circumstances in 1990. In the 1980s the liberal Orthodox Christians found a guiding figure in Men', who was critical of the state of the ROC of his day. Among his friends and followers were Averintsev and Khoruzhi. Men' preached a church independent of the state, socially engaged in the world, and ready to support democratic politics. Needless to say, Men' was not well received by the hierarchs of the Moscow Patriarchate which was in the process of staking its claim to the Russian nation. Men' stood in the tradition of liberal Orthodoxy which reaches back to Solov'yev's criticism of state-church relations and to Bulgakov's advocacy of a socially engaged church. Their legacy finds continuation today, its primary representative being the priest Georgi Kochetkov, who was exposed to disciplinary measures by the Moscow Patriarchate for being 'too liberal' (Kostjuk, 2005, p. 118-22).

23 An important figure in this respect is Metropolitan Kirill (Gundyayev) of Smolensk and Kaliningrad, head of the ROC's Department of External Affairs. For a detailed analysis of the theological position of Metropolitan Kirill see Kostjuk, 2005, pp. 128-38.

$24 \quad$ Numerous scholars have pointed out the growing salience of Orthodox fundamentalism. See for example: Makrides and Uffelmann, 2003; Scherrer, 2003.

25 It has to be borne in mind that number of active Orthodox believers in Russia has not risen significantly in the postcommunist period. Statistical data show that, while the number of believers rose immediately after 1991, numbers fell again once the disillusioning involvement of the ROC with the communist regime became apparent and once people realised that the ROC had little to offer in the difficult years of the 1990s. Studies make it clear that religiosity in Russia is not on the rise, or at least not as much as the public attention paid to the ROC would suggest. See: Kaariainen and Furman, 1997; Filatov, 2002. 